\title{
THE OPEN DOOR TO PREVENT COUNTERPRODUCTIVE WORK BEHAVIOR: ETHICAL LEADERSHIP
}

\author{
Halime GÖKTAŞ KULUALP *, Cenk Murat KOÇOĞLU**
} \begin{abstract}
The aim of this study is to determine the effect of ethical leadership behavior on counterproductive behaviors. Data were obtained using the survey technique. The sample of the study consists of 252 employees who work in four - and five star hotels in Istanbul. According to the results of the analysis, it is found that the "abuse" dimension is the most powerful dimension in order to explain counterproductive work behavior. Counterproductive business behavior is negatively affected by ethical leadership behaviors. In addition, ethical leadership has a negative impact on behaviors related to abuse, withdrawal, theft, sabotage, and deviation from production and service, which have counterproductive business behavior dimensions.
\end{abstract}

Keywords: Ethical Leadership. Counterproductive Work Behaviors. Hotel Employees.

\section{A PORTA ABERTA PARA EVITAR O COMPORTAMENTO CONTRA-PRODUTIVO: LIDERANÇA ÉTICA}

Resumo

0 objetivo deste estudo é determinar o efeito do comportamento de liderança ética em comportamentos contraproducentes. Os dados foram obtidos usando a técnica de pesquisa. A amostra do estudo consiste em 252 funcionários que trabalham em hotéis de quatro e cinco estrelas em Istambul. De acordo com os resultados da análise, verifica-se que a dimensão "abuso" é a dimensão mais poderosa para explicar o comportamento contraproducente. 0 comportamento comercial contraproducente é afetado negativamente por comportamentos éticos de liderança. Além disso, a liderança ética tem um impacto negativo nos comportamentos relacionados a abuso, retirada, roubo, sabotagem e desvio da produção e do serviço, que têm dimensões de comportamento de negócios contraproducentes.

Palavras chave: Liderança Ética. Comportamentos de Trabalho Contraproducente. Funcionários do Hotel.

\section{LA PUERTA ABIERTA PARA PREVENIR EL COMPORTAMIENTO DE TRABAJO CONTRAPRODUCTIVO: LIDERAZGO ÉTICO}

Resumen

El objetivo de este estudio es determinar el efecto del comportamiento de liderazgo ético en los comportamientos contraproducentes. Los datos se obtuvieron mediante la técnica de la encuesta. La muestra del estudio consta de 252 empleados que trabajan en hoteles de cuatro y cinco estrellas en Estambul. De acuerdo con los resultados del análisis, se encuentra que la dimensión "abuso" es la dimensión más poderosa para explicar el comportamiento contraproducente. El comportamiento comercial contraproducente se ve afectado negativamente por los comportamientos de liderazgo ético. Además, el liderazgo ético tiene un impacto negativo en los comportamientos relacionados con el abuso, el retiro, el robo, el sabotaje y la desviación de la producción y el servicio, que tienen dimensiones de comportamiento comercial contraproducente.

Palabras clave: Liderazgo Ético. Comportamientos de Trabajo Contraproductivos. Empleados de Hotels.

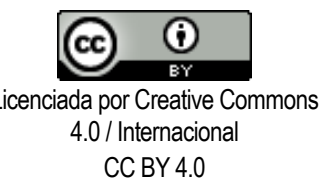

* Ph.D. in Business Management (2015) at Bulent Ecevit University. She is assistant professor at the Department of Tourism Management at Karabuk University. Her research interests business management, human resources management, organizational behavior, Adress: Yeni Mahalle Mah. Prof. Metin Sözen Cad. 78600 Safranbolu/KARABÜK (ORCID ID: 0000-0002-1485-3026); [ halime goktas@hotmail.com ].

${ }^{* *}$ Ph.D. in Business Management (2016) at Bulent Ecevit University. He is assistant professor at the Department of Tourist Guiding at Karabuk University. His research interests tourism marketing, tourism management, service quality and brand equity Adress: Yeni Mahalle Mah. Prof. Metin Sözen Cad. 78600 Safranbolu/KARABÜK (ORCID ID: 0000-0002-9888-6051); [ cenk-murat@hotmail.com ]. 


\section{INTRODUCTION}

Today, concepts such as globalization, intensifying competition, and dizzying period of change have taken their businesses under their own control. These transformations have caused a change in working conditions in businesses and have enabled concepts belonging to the working life such as justice, ethics, commitment and loyalty to gain more importance.

Because rapid changes have caused workers to spend more time in their workplaces than with their family. Therefore, it can be said that employees forge a link between their colleagues, almost as much as the relationship with their family. In business life, which constitutes an important part of life, attitudes and behaviors of individuals are of great importance both for their own mental and physical health and for the functioning of the organization itself.

Dedeoğlu, Aydın and Boğan (2018, p.94) stated that enterprises should give importance to their behaviors in order to gain advantage in the intense competition environment. Because, organizational perceptions, evaluations, impressions and attitudes of consumers can be shaped by employee behavior. Therefore, conducting a study on how employees' attitudes and behaviors develop in the work environment and which factors are affected will produce valuable results.

One of the negative behaviors that employees can demonstrate in their workplaces is their counterproductive work behavior. These behaviors result in the damage of employees to organizational order or other members of the organization in business life. These results will be reflected both to the organizational performance and to the individuals in the organization negatively. These aforementioned losses are counter-productive business behaviors such as sabotage, theft, waste of work time, concerning with offthe-job acts during working hours, not sharing information with other employees, and abuse of organizational resources.

Especially in the tourism sector where this study is conducted, information production is an indicator of the institutionalization and maturation of the organization (Pimentel \& De Paula, 2019; Pimentel, Carvalho \& Pimentel, 2016). Therefore, it can be said that information production and accurate information sharing are important in preventing anti-productivity business behaviors in the enterprise.

Considering the major loss these kinds of behaviors cause to the business, it will be understood how important it is to prevent these negative business behaviors. For this reason, it has been observed that studies examining negative business behavior in the literature (Arıkök \& Çekmecelioğlu, 2017; Taşlıyan, Hirak, Çiftçi \& Fidan, 2016; Tuna \& Boylu, 2016; Kanten \& Ülker, 2014; Resick et al., 2013; Kessler et al., 2013; Yeşiltaş et al., 2012; Liu et al., 2012) show an increase in the last 5 years.

On the other hand, it is thought that counterproductive work behavior, one of the negative business behaviors, does not find itself enough research areas in the literature.

Ethical leadership is a modern leadership approach in which the employee trusts his / her executive at a high level. Ethical leaders can enable their employees to exhibit positive business attitudes and behaviors in harmony with the moderate atmosphere they create within the organization.

Therefore, it is very important to concretely reveal the effect of ethical leadership on the prevention of counterproductive work behavior, which is the result of an understanding that damages business assets. However, it has been observed that the number of studies carried out on this subject (Liu et al., 2012; Detert et al., 2007; Arıkök \& Çekmecelioğlu, 2017) is very limited. Therefore, it is foreseen that this research will close the gap in the field of counterproductive work behavior and ethical leadership in the literature.

In this study, which examines the counterproductive behaviors, which is a factor that reduces productivity and performance in the business it has been examined whether ethical leadership behavior is a way to reduce counterproductive behaviors.

\section{THEORETICAL REVIEW}

\subsection{Counterproductive work behaviors}

Counterproductive work behaviors are behaviors aimed at harming the organization and its members (Martinko et al., 2002, p. 37). On the other hand, counterproductive work behaviors are defined by Sackett $(2002$, p. 5) as intentional behaviors that are contrary to the legal interests of the organization.

According to Le Roy et al. (2012, p. 1342), these behaviors in general cause harm to the organization and its members in a conscious and systematic manner. Counterproductive work behaviors are behaviors that target directly the organization and its stakeholders (managers, colleagues, subordinates, customers, etc.), that are consciously carried out and that the intention to do harm is clearly demonstrated or concealed (Spector \& Fox, 2002).

The counterproductive work behavior is industrial sabotage. In other words, it is the behavior that employees do not do their work by acting in a manner that prevents the organization from working efficiently. 
Employees' stealing, disrupting, harming, wasting and using alcohol or drugs at work, and any unacceptable behavior that conforms to the above definition is described as counterproductive work behaviors.

All these behaviors lead organizations to incur large amounts of financial loss (Moretti, 1986, p. 134). This concept includes behaviors that violate the norms of the organization and endanger its well-being, which is displayed discretionally by the employees. (Cited by Yen \& Teng 2012, p. 2 from Bennett and Robinson, 1995).

It is seen that the studies that deal with counterproductive work behaviors are directed against the organization and the individual, the degree of severity of the behavior, the source and the degree of violation of organizational norms (O'Boyle et al., 2011, p. 41). Counterproductive work behaviors can be committed against the organization or the organization employee (Fox \& Spector, 1999). Counterproductive work behaviors are behaviors that directly affect the goals and functions of the organization and harm all processes and employees of the organization and thus reduce the organizational efficiency (Mann et al., 2012, p. 142).

It is observed in the literature that the counterproductive work behavior is classified differently according to the authors. Neumann and Baron (1998) stated that the counterproductive work behaviors were grouped under three factors: hostile behavior, preclusion and covert aggression. Hollinger and Clark (1983) examine counterproductive work behaviors in two dimensions.

The first dimension is deviant behavior against property, which includes behaviors of employees such as the abuse of the business's assets, theft, destruction of property and abuse of discount privileges. The second dimension is behaviors that can negatively affect production such as the violation of the rules that should be followed, being late to work, absenteeism, long breaks, and the use of alcohol and drugs.

The most widely accepted counterproductive work behavior dimension in the literature belongs to Spector et al. (2006). According to this dimension, counterproductive work behaviors are examined in five dimensions, including abuse, deviation from production, sabotage, theft and withdrawal.

It is possible to address the counterproductive work behaviors on an interindividual and organizational level. Interindividual counterproductive work behaviors arise as a result of the relationships between the individuals or by suppressed emotions in the subconscious of individuals.

The fact that individuals humiliating each other, gossiping, being rude, mocking each other, fighting each other and physically harassing each other are evaluated within the context of interindividual counterproductive work behaviors (Kanten \& Ülker, 2014, p. 23).

Counterproductive work behaviors in the organizational dimension are negative behaviors aimed at the whole organization and at the goals and objectives. Workplace deviance can be considered as antisocial behavior, undesirable organizational behavior, aggression, retaliation behavior and disobedience (Demirel, 2009, p. 123).

\subsection{Ethical leadership}

Ethics is a philosophical discipline that examines the values that form the main elements in human and social relations from a moral point of view, such as right-wrong, good-bad (Şimşek et al., 2011, p. 474). As it is understood from the definition, morality and ethics are concepts related to each other. In the literature, it is possible to see that the concepts of ethics and morality are used interchangeably. Since it is not possible to separate these two concepts from each other with precise borders, both concepts intertwine in the definition of each other (Sabuncuoğlu, 2011, p. 3).

Although many leadership definitions have been made until today, a consensus on its definition has not yet been developed (Bass, 1990, p. 18). However, in the most general form in the literature, the leader is defined as a sum of knowledge and skills to persuade people and to guide them in line with the set goals and to mobilize them to achieve those goals. (Davis, 1988, p. 141).

The importance of ethical values in leadership is not a situation that comes into prominence today. Throughout human history, the emphasis was placed on the importance of ethics (Aktan, 1999, p. 99). Yusuf Has Hacib, in his Kutadgu Bilig work he wrote in 19691970, spoke of ethical traits such as being truthful, honest, just, trustworthy, courageous, patient and calm, humble, moderate and generous, and not having mischief and bad habits (Sezgül, 2010, p. 244).

However, the concept of ethical leadership has gained more importance in working life with ethical scandals occurring within the structure of large companies in the world after the 1990s (Aronson, 2001, p. 245; Tuna et al., 2012, p. 144). Scandals in global enterprises such as Enron, WorldCom and Parmalat have triggered the discussion of joint management, business ethics and the ethical responsibility of leader (May et al., 2003, p. 247).

The ethical leader is the one who distinguishes the right from the wrong and does the right and seeks justice, integrity and goodness in the leadership process (Cited by Çengelci, 2014 from Daft, 2008, p. 170). In its most broad definition, ethical leadership is 
the ability of the leader to adhere to ethical values and to relate his / her behavior to ethical values (Cuilla, 1998). Ethical leaders embody the goals, vision and values of the organization in an ethical understanding. Inspiring the employees in the organization by building trust, keeping their word is one of the most important features that make a leader an ethical leader (Cemaloğlu \& Kııınç, 2012, p. 140-141).

The main purpose of leadership behavior is to influence the activities of the members of the organization. The influence of the activities will be reflected in the behavior of the employees and will enable the organization to achieve its objectives. The role behaviors, strategies and tactics of the leader affect the values, beliefs and behaviors of the audience, as well as the achievement of tasks and the adaptation of the organization (Arslantaş \& Dursun, 2008, p. 112).

Ethical leadership is defined as a form of leadership to influence subordinates based on ethical power (Çelik, 2003). For this reason, ethical leaders are leaders who consistently keep fair practice on the agenda by behaving right and honest (Brown et al., 2005). These leaders have the ability to act proactively and make the right decision in the face of actions.

Therefore, leaders need to be ethically mature in order to succeed (Yaman, 2010, p. 11). Ethical leadership requires the demonstration of ethical management practices through personal behavior, attitudes, discourses and interpersonal relationships, as well as the encouragement and strengthening of attitudes and behaviors mentioned in the bilateral relations established with employees (Brown et al., 2005 , p. 120).

\subsection{The relationship between ethical leadership and counterproductive work behavior}

Counterproductive work behaviors arise as a result of employees' negative perception of organizational conditions (Kanten \& Ülker, 2014, p. 24). On the other hand, a leader's understanding of management affects the performance, attitude and behavior of individuals, thus contributing to the increase or decrease of organizational performance (Uche \& Timinepere, 2012, p. 200).

It is, therefore, possible that the employees involved in the organization of a leader who adopts ethical and fair practices within the organization will provide positive returns to the organization (such as showing commitment to the organization, developing the sense of organizational belonging, and not displaying counterproductive behaviors).

On the contrary, a leader's style of management, which does not support the individual objectives of the workers, does not allow them to participate in decisions, and is not perceived as fair, leads to alienation (Ceylan \& Sulu, 2010, p. 67). Alienation, on the other hand, is a factor that can increase the counterproductive behaviors within the organization. Such that, Kanten \& Ülker (2014, p. 30) determined that alienation has a positive-orientation and significant effect of 35,4 units on counterproductive work behavior.

Ethical leadership is an attitude that is conducive to the wellbeing of the employee in the workplace. State of wellbeing in the workplace is related to ethical leadership, organizational trust and organizational support.

Ethical leadership affects organizational trust positively (Taşısıan, Hırlak, Çiftçi \& Fidan, 2016, p. 2541). Tuna and Boylu (2016) found that perceived organizational support positively affects the positive affective well-being of the work, while perceived organizational support negatively affects the state of negative towards the work. In addition, they determined that perceived organizational support has a positive effect on the extent of theft, withdrawal and misuse dimensions, which are dimensions of counterproductive work behaviors.

Consequently, employees, who perceive a management style that contributes to their positive and individual goals, are expected to exhibit positive attitudes and behaviors while in the case of perceiving a negative management style, it is possible for employees to exhibit harmful behaviors (Kanten \& Ülker, 2014, p. 25).

Liu et al. (2012) examined the relationship between ethical leadership and counterproductive work behaviors and found that ethical leadership helps to limit workplace deviations of the subordinates. As the ethical leader approaches moral practice more and more, there has been a decrease in the counterproductive behavior of the employee.

Detert et al. (2007) investigated the effect of three types of managerial functions, namely managerial oversight, ethical leadership and abusive auditing on counterproductive work behaviors in food and beverage businesses. It has been determined that exploitative supervision and managerial oversight reduced work behaviors against production, but ethical leadership did not have a statistically significant impact on work behaviors against productivity. Resick et al. (2013), in the study they conducted, supported the hypothesis that ethical leadership is associated with negative ethical value judgments about workplace deviance of employees.

Kessler et al. (2013) examined the effect of leadership on interpersonal conflict and counterproductive work behaviors. According to the research findings, leadership style and interpersonal conflict affect the negative emotions of the individual 
and ultimately leads to counterproductive work behaviors.

Yeşiltaş et al. (2012) in their research to determine the impact of ethical leadership activities on organizational justice and counter-organizational productivity work behaviors, concluded that there is a negative correlation between ethical leadership behavior and deviation behaviors and that ethical leadership activities reduce deviation behaviors. In this respect, the following hypotheses are produced based on the aforementioned theoretical knowledge and discussion:

$\mathrm{H} 1$ : Counterproductive work behaviors in the workplace are negatively affected by the ethical leadership behavior perceived by employees.

H1a: Abuse, one of the counterproductive work behaviors in the workplace is negatively affected by the ethical leadership behavior perceived by employees.

$\mathrm{H} 1 \mathrm{~b}$ : Withdrawal, one of the counterproductive work behaviors in the workplace is negatively affected by the ethical leadership behavior perceived by employees.

H1c: Theft, one of the counterproductive work behaviors in the workplace is negatively affected by the ethical leadership behavior perceived by employees.

H1d: Sabotage, one of the counterproductive work behaviors in the workplace is negatively affected by the ethical leadership behavior perceived by employees.

H1e: Production and service deviation, one of the counterproductive work behaviors in the workplace is negatively affected by the ethical leadership behavior perceived by employees.

\section{RESEARCH METHODOLOGY}

In the methodology part, the purpose of the study, relations and hypotheses between variables, universe and sampling and data collection method topics were mentioned.

\subsection{Purpose and hypotheses}

Today, a new concept that damages businesses and needs to be prevented has emerged. This concept of "counterproductive work behavior" has become an incident that leaves enterprises in a difficult situation, even causing serious harm to them.

The fastest growing crime in North America is workplace fraud and employee theft. This incident has a negative impact on all kinds of businesses and this loss costs $1 \%$ to $2 \%$ of the average annual sales (Coffin, 2003). However, these rates belong only to the part that can be calculated.

On the other hand, there are loss items that are very difficult or even impossible to calculate. It is inevitable to take the necessary measures to prevent an incident that leaves businesses in such a difficult situation. Therefore, in this study, it is aimed to determine the effect of ethical leadership behavior as a way of preventing counterproductive work behaviors.

While there are a large number of studies on ethical leadership and counterproductive work behavior in the literature (Liu et al., 2012; Detert et al., 2007; Arıkök \& Çekmecelioğlu, 2017), it has been observed that there is a limited number of studies examining ethical leadership behavior as a way of preventing counterproductive work behavior.

In this context, it is foreseen that this study will contribute to the literature by combining the concepts of ethical leadership and counterproductive work behaviors and examining their interactions.

\subsection{Population and sample}

In the research, the employees of the five-star hotels located in the Anatolian side of Istanbul constitutes the universe. As the sampling method, the convenience sampling method from non-random sampling methods was used.

The research was carried out in March-April 2018 period. There is a total of 14 five-star hotels on the Anatolian side. As a result of the interviews made with these hotels, the application was conducted through 4 hotels that accepted the application proposal.

Due to the fact that the number of employees of the aforementioned hotels cannot be determined, in order to determine the universe of the study, the employees per bed (0.59) in five-star hotels included in the literature were accepted (Erdem, 2004, p. 48). Based on this assumption, it was assumed that 700 employees $(1186 \times 0,59)$ were employed in fivestar hotel enterprises with 1186 beds, constituting the universe of the research.

In order to represent the overall results in the best way, the number of samples required to be reached with $95 \%$ reliability and $5 \%$ error rate is 248 according to Sekaran (2003, p. 294). In this context, 350 questionnaires were left and 260 were filled with $80 \%$ return rate. Among the applied questionnaires, 252 healthy ones were included in the analysis.

\subsection{Data collection method and scales}

Within the scope of the research, the data were obtained with the questionnaire technique. The first part of the questionnaire belongs to ethical leadership, the second part belongs to counterproductive work behaviors and the last part belongs to demographic information. As demographic information, participants 
were asked questions about their age, gender, educational status, working time, department held and job position.

In order to measure ethical leadership behavior, the 10-item scale developed by Brown et al. (2005) was used. In the literature, this 10 -item scale developed by Brown et al. in 2005 was considered to be a reliable scale of ethical leadership (Yeşiltaş, Çeken \& Sormaz, 2012, p. 26; Arslantaş \& Dursun 2008, p. 117).

The appropriateness, validity and reliability of this scale for its use in Turkish was achieved by Tuna et al. (2012, p. 26). In the scale, a 5-point Likert type scale was used with (1) Strongly Disagree, (2) Agree, (3) Undecided (4) Agree, (5) Strongly Agree.

The checklist for counterproductive work behaviors was created using the study of Spector et al. (2006). The aforesaid checklist consists of 33 articles. It is examined under five factors: sabotage, abuse, theft, deviation from production and withdrawal.

The scale was transformed into a 5-point Likert type scale with (1) Strongly Disagree, (2) Agree, (3) Undecided (4) Agree, (5) Strongly Agree. While Spector calculated Cronbach reliability coefficient of the scale as 0.850 , Kilıç (2013) found 0.922 in research he conducted in Turkey. This finding shows that the scale has a high level of reliability within the Turkish sample.

\subsection{Findings of the research}

It is seen that a large majority of the employees participated in the study, approximately $73 \%$ (183), consisted of males. When the age of the employees is examined, the largest group is composed of 33- to 35year-olds (109) and the smallest group is composed of 45 years and over (7). When the education level of the employees is examined, the employees with associate degrees (85) constitute the majority with approximately $34 \%$. When the departments where the employees are employed are examined, it is observed that most of the employees work in food and beverage department with $36 \%$ (92) and in housekeeping department with $29 \%$ (73). When the working times of the employees participated in the research are examined, it is seen that most of them work for 7-12 months (75). When the job position of the employees in the workplace is looked at, a big majority of them, $72 \%$ (181), work in lower levels. This information is shown in Table 1 in the appendix.

Descriptive factor analysis was carried out in order to reveal the dimensional structures of the two scales related to the ethical leadership behavior of the employees working in the hotel enterprises and counterproductive work behaviors and to determine their validity and reliability. First, the reliability analysis was performed on both scales and the reliability level of the ethical leadership behavior scale was determined to be $94 \%$ and the reliability level of the counterproductive work behaviors scale was determined to be $94 \%$ again. This information is shown in Table 2 in the appendix.

According to Kaiser normalization, factor analysis based on factors whose eigenvalue is greater than 1 , it was determined that the scale of ethical leadership behavior consists of one dimension. The percentage of variance of the study was found to be 66,30 . Since this rate is higher than $50 \%$, the analysis seems to be valid (Scherer et al., 1988).

As a result of the explanatory factor analysis for counterproductive work behaviors, the factor load of the expression "Although I had completed a given task on time, I told them that I could not complete the task yet so that no new task could be assigned" was less than $40 \%$, and it was excluded from the analysis and according to Kaiser normalization, considering the big factors with eigenvalues greater than 1 , it has been revealed that the scale is made up of 5 dimensions.

The total of the variance percentage of the research was found to be 69,34 . Reliability analysis of each emerging dimension has been performed and the dimensions which constitute the counterproductive work behaviors scale have emerged as "abuse" $97 \%$, "withdrawal" 94\%, "theft" $89 \%$, "sabotage" $82 \%$ and "production and service deviation" $91 \%$.

Table 3: Means of Ethical Leadership and Counterproductive Work Behaviors Dimensions.

\begin{tabular}{|l|l|l|}
\hline Dimesions & Average & S. Deviation \\
\hline Ethical Leadership Work & 3,68 & 0,91345 \\
\hline $\begin{array}{l}\text { Counterproductive } \\
\text { Behaviors }\end{array}$ & 1,62 & 0,60263 \\
\hline Abuse & 1,5 & 0,72876 \\
\hline Withdrawal & 1,75 & 0,85514 \\
\hline Theft & 1,39 & 0,60167 \\
\hline Sabotage & 1,69 & 0,61284 \\
\hline Production/Service Deviation & 1,75 & 0,90635 \\
\hline
\end{tabular}

Source: proper elaboration.

In Table 3, ethical leadership and counterproductive work behaviors and their subdimensions are listed. First of all, when looked at the mean of the "ethical leadership" dimension, it was determined to be 3,68 .

Accordingly, it is considered that managers in hotel management conduct an ethical leadership attitude toward the employees, when looked at the mean of the "counterproductive work behaviors" dimension, it was determined to be 1,62. Looking at the mean of sub-dimensions of counterproductive work behavior, they are ranked from lowest to highest as "theft" (1.39), "abuse" (1.50), "sabotage" (1.69), 
"production and service deviation" (1.75) and "withdrawal" (1.75). Accordingly, it can be said that the employees working in the hotel enterprises do not generally exhibit counterproductive work behaviors.

A correlation analysis was carried out between ethical leadership behavior in hotel enterprises and counterproductive work behaviors. In the research, it is generally accepted that there is a strong relation between the variables, if $n>100$ and $r>0.70$. If $r=$ between 0.40 and 0.70 , it is considered as "moderate", $r=$ between 0.20 and 0.40 as weak relationship and $r=$ less than 0.20 as "very weak" (Sökmen, 2000). Pearson correlation test results are shown in Table 4.

Table 4: Correlation Analysis Related to Correlation Between Variables.

\begin{tabular}{|l|l|l|l|l|l|l|}
\hline & EL & CWB & A & WD & T & S \\
\hline $\begin{array}{l}\text { Ethical } \\
\text { Leadership }\end{array}$ & 1 & & & & & \\
\hline $\begin{array}{l}\text { Counterprod } \\
\text { uctive Work } \\
\text { Behaviors }\end{array}$ &,$- 398^{*}$ & 1 & & & & \\
\hline Abuse &,$- 420^{*}$ &, $911^{*}$ & 1 & & & \\
\hline Withdrawal &,$- 252^{*}$ &, $809^{*}$ & 0,551 & 1 & & \\
\hline Theft &,$- 170^{*}$ &, $554^{*}$ &, $367^{*}$ &, $445^{*}$ & 1 & \\
\hline Sabotage &,$- 185^{*}$ &, $705^{*}$ &, $558^{*}$ &, $545^{*}$ &, $324^{*}$ & 1 \\
\hline $\begin{array}{l}\text { Production/ } \\
\text { Service } \\
\text { Deviation }\end{array}$ &,$- 402^{*}$ &, $759^{*}$ &, $648^{*}$ &, $570^{*}$ &, $380^{*}$ & $\begin{array}{l}, 507 \\
*\end{array}$ \\
\hline
\end{tabular}

Source: proper elaboration.

Looking at the relationship between ethical leadership and counterproductive work behavior and its sub-dimensions, while a weak negative relationship was determined between ethical leadership and counterproductive work behaviors $(r=-, 398)$, ethical leadership and counterproductive work behavior abuse was determined as $(\mathrm{R}=-, 420)$ and production and service deviation was determined as $(r=-, 402$; a moderate and significant relationship with ethical leadership, a weak negative and significant relationship withdrawal $(r=-, 252)$ and a very weak negative significant relationship between theft $(=-, 170)$ and sabotage $(r=-, 185)$ were determined. According to this, as the ethical leadership behavior of the managers in hotel enterprises increase, it is evaluated that the employees avoids counterproductive work behaviors.

The effects of ethical leadership behavior on production behavior and its sub-dimensions on simple regression analysis are shown in Table 5 (appendix). According to the first model, simple regression analysis for the effect of ethical leadership behavior on counterproductive work behavior was found to be statistically significant $(F=47,01 ; p=0.000)$.

According to the model, the explanatory rate of ethical leadership behavior of counterproductive work behaviors is $15,8 \%$. When the T-test results for the standardized regression coefficient and the significance of regression coefficient were examined, it was determined that ethical leadership behavior $(\mathrm{H} 1$, $\beta=-, 398 p=0.000$ ) had a significant and negative effect on counterproductive work behaviors and it was determined that the corresponding hypothesis was accepted. This information is shown in Table 5 in the appendix.

According to the second model, regression analysis was found to be statistically significant to determine the effect of ethical leadership behavior on the dimension of abuse $(F=53,41 ; p=, 000)$. According to the model, the explanatory rate of ethical leadership behavior of abuse dimension of counterproductive work behaviors is $17,6 \%$.

When the T-test results for the standardized regression coefficient and the significance of regression coefficient were examined, it was determined that ethical leadership behavior $\left(H_{1 a}, \beta=-\right.$ , $420 p=0.000$ ) had a significant and negative effect on the dimension of abuse of counterproductive work behaviors and it was determined that the corresponding hypothesis was accepted.

According to the third model, regression analysis was found to be statistically significant to determine the effect of ethical leadership behavior on the dimension of withdrawal $(F=17,05 ; p=, 000)$. According to the model, the explanatory rate of ethical leadership behavior of withdrawal dimension of counterproductive work behaviors is $6,4 \%$.

When the T-test results for the standardized regression coefficient and the significance of regression coefficient were examined, it was determined that ethical leadership behavior $\left(H_{1 b}, \beta=-\right.$ , $252 p=0.000$ ) had a significant and negative effect on the dimension of withdrawal of counterproductive work behaviors and it was determined that the corresponding hypothesis was accepted.

According to the fourth model, regression analysis was found to be statistically significant to determine the effect of ethical leadership behavior on the dimension of theft $(F=7,441 ; p=, 007)$. According to the model, the explanatory rate of ethical leadership behavior of theft dimension of counterproductive work behaviors is $17,6 \%$.

When the T-test results for the standardized regression coefficient and the significance of regression coefficient were examined, it was determined that ethical leadership behavior $\left(\mathrm{H}_{1 \mathrm{c}}, \beta=\right.$ , $170 p=0.007$ ) had a significant and negative effect on the dimension of theft of counterproductive work behaviors and it was determined that the corresponding hypothesis was accepted.

According to the fourth model, regression analysis was found to be statistically significant to 
determine the effect of ethical leadership behavior on the dimension of sabotage $(F=8,899 ; p=, 003)$.

According to the model, the explanatory rate of ethical leadership behavior of theft dimension of counterproductive work behaviors is $3 \%$. When the Ttest results for the standardized regression coefficient and the significance of regression coefficient were examined, it was determined that ethical leadership behavior $\left(H_{1 d}, \beta=-, 185 p=0.003\right)$ had a significant and negative effect on the dimension of sabotage of counterproductive work behaviors and it was determined that the corresponding hypothesis was accepted.

According to the last, regression analysis was found to be statistically significant to determine the effect of ethical leadership behavior on the dimension of production and service deviation ( $F=48,12 ; p=, 000)$. According to the model, the explanatory rate of ethical leadership behavior of production and service deviation dimension of counterproductive work behaviors is $16,1 \%$.

When the T-test results for the standardized regression coefficient and the significance of regression coefficient were examined, it was determined that ethical leadership behavior $\left(\mathrm{H}_{1 \mathrm{e}}, \beta=-\right.$ , $402 p=0.000$ ) had a significant and negative effect on the dimension of production and service deviation of counterproductive work behaviors and it was determined that the corresponding hypothesis was accepted.

According to all these models, it was revealed that counterproductive work behaviors have negatively affected the sub-dimensions of ethical leadership behavior. According to this, the ethical leadership behavior of managers in hotel enterprises will reduce counterproductive work behaviors of employees.

\section{DISCUSSION AND CONCLUSIONS}

This research addressed the subject of counterproductive work behaviors and was conducted to determine the effect of ethical leadership on counterproductive work behaviors. Within the scope of the model, it is foreseen that hotel employees' perceptions of ethical leadership practices of their managers will prevent or reduce their ability to show counterproductive work behaviors.

According to analysis results, it was determined that employees' counterproductive work behavior perceptions are low since employees' counterproductive work behaviors $(1,62)$ and subdimensions of counterproductive work behaviors abuse $(1,50)$, withdrawal $(1,75)$, theft $(1,39)$, sabotage $(1,69)$ are placed in the 1,00-1,80 range, which is the borders of the expression "Strongly disagree" and that the ethical leadership scale is higher than the threshold of "I agree" with an average of $(3,68)$, it is determined that the perception of ethical leadership of employees in the workplace is higher.

Counterproductive work behaviors are a type of behavior that occurs as a result of negative attitudes that employees harbor against the work environment. At this point, it is important to ensure that employees have a positive attitude towards their institutions. Making leader qualified managers continuously evaluate the employee's job positions and to investigate the reasons underlying the events that lead the employee to negative behaviors by intervening and drawing conclusions may be a measure to prevent negative attitudes.

Therefore, ethical leadership, which is one of the types of ethical climate structure or leadership, has been proven by some studies in the literature (Liu et al., 2012; Detert et al., 2007; Resick et al., 2013; Yeşiltaş et al., 2012; Arıkök \& Çekmecelioğlu, 2017) in which employees are influenced by reducing their counterproductive work behavior.

Organizational and managerial efficiency, which have become very important especially in today's world, can be achieved through the effective use of human resources (Ayaz and Göktaş Kulualp, 2019: 275). Ethical leaders' efforts to prevent counterproductive work behaviors serve this purpose.

According to the findings of the research hypothesis, ethical leadership behavior $(\beta=-0.398)$ has a significant and negative effect on counterproductive work behaviors. In addition, it has been determined that ethical leadership behavior has a negative and significant effect on the counterproductive work behaviors dimensions, abuse $(\beta=-0.420)$, withdrawal $(\beta=-0.252)$, theft $(\beta=-0701)$, sabotage $(\beta=-0185)$ and production and service deviation ( $\beta=-0402)$.

Therefore, the results obtained as a result of the analysis show similar results with limited number of research (Liu et al., 2012; Detert et al., 2007; Arıkök and Çekmecelioğlu, 2017) examining the relationship between ethical leadership and counterproductive work behaviors. However, among these researchers, Liu et al. (2012) and Detert et al. (2007) discussed counterproductive work behaviors on the basis of basic dimension.

The dimensions of counterproductive work behaviors examined by Arıkök and Çekmecelioğlu (2017) differ from the sub-dimensions of this research. In other words, there was no study conducted on the effect of ethical leadership on the sub-dimensions of counterproductive work behaviors, which are abuse, withdrawal, theft, sabotage and production and service deviation was found in the literature.

In this respect, it is thought that the research will 
fill this gap in the literature. In fact, it is foreseen that this study will contribute to the working life in practice in terms of understanding what kind of ethical leadership is more effective on counterproductive work behavior and fighting effectively with counterproductive work behaviors, which are among negative work attitudes.

In the light of the findings obtained within the scope of the research, the managers were tried to show the issues that could be taken into consideration in the prevention of counterproductive work behaviors in the working environment.

In this context, it can be said that if managers can strengthen their perception of their employees' ethical leadership behavior, they will face less counterproductive work behaviors. In addition, ethical leadership negatively affects the abuse of counterproductive work behaviors by the highest level and production and service deviation in the second place.

This sequence is followed by withdrawal, sabotage and theft. Therefore, this negative behavior can be resolved with ethical leadership in a business where abuse of position and authority is arising. Especially in tourism enterprises, quality can be provided by the quality behaviors of employees (Tekeli and Buyruk, 2018:34). In this respect, it can be said that the success of the service sector is hidden in showing the right business behaviors of the employees.

The fact that the study was applied only to hotel employees constitutes the limited aspect of the study. Therefore, the study should be tested in different sectors to determine whether ethical leadership is a solution to prevent or reduce counterproductive work behaviors by testing the model for future work.

At the same time, counterproductive work behaviors were examined only in the ethical leadership perspective in this study. In future studies, focusing on different variables will contribute to the increase in the number of studies and measures to prevent negative work behaviors.

\section{REFERENCES}

Arkök, M., \& Gündüz Çekmecelioğlu, H. (2017). Etik liderliğin üretim karşıtı iş davranışları üzerindeki etkisi: Ankara üretim sektöründe bir uygulama. Journal of International Social Research, 10 (52), 915-928. http://dx.doi.org/10.17719/jisr.2017.1946

Aronson, E. (2001). Integrating leadership styles and ethical perspectives. Canadian Journal of Administrative Sciences, $18 \quad$ (4), 244- 256. https://doi.org/10.1111/j.1936-4490.2001.tb00260.x

Arslantaş, C. \& Dursun, M. (2008). Etik liderlik davranışının yöneticiye duyulan güven ve psikolojik güçlendirme üzerindeki etkisinde etkileşim adaletinin dolayıı rolü, Anadolu Üniversitesi Sosyal Bilimler Dergisi, 8 (1),
111-127. from http://sbd.dergi.anadolu.edu.tr/yonetim/icerik/makalele r/1237-published.pdf

Ayaz, N.\& Göktaş Kulualp, H. (2019). Strategic role of human resource management in tourism enterprises, In Recep Efe, Irina Koleva, Münir Öztürk, Ramiz Arabacı (Ed), Recent advances in social sciences (p. 275-289), $1^{\text {th }}$ Edition, Cambridge Scholars Publishing, ISBN:15275-1954-6.

Bass, B.M., (1990). Bass \& Stogdill's handbook of leadership, theory, research, and managerial applications, $3^{\text {th }}$ Edition, New York, The Free Press.

Brown, M. E., Trevino, L. K. \& Harrison, D. A. (2005). Ethical leadership: A social learning perspective for construct development and testing, Organizational Behavior and Human Decision Processes, 97, 117- 134. https://doi.org/10.1016/j.obhdp.2005.03.002

Ceylan, A. \& Sulu, S. (2010). Work alienation as a mediator of the relationship of procedural injustice to job stress. International Journal of Business and Management, 5 (8), 65-74. https://doi.org/10.2478/v10033-010-0016-1

Ciulla, J. B. (1995). Leadership ethics: Mapping the territory. Business Ethics Quarterly, 5(1), 5-28. from https://www.jstor.org/stable/3857269

Coffin, B. (2003). Breaking the silence on white collar crime. Risk Management, 50, 8.

Çelik, V., 2003. Eğitimsel liderlik. Ankara: Pegem A Yayıncllik.

Çengelci, E. (2014). Okul yöneticilerinin etik liderlik davranışları, Afyon Kocatepe Üniversitesi Sosyal Bilimler Enstitüsü, Yayınlanmamış Yüksek Lisans Tezi, Afyon.

Daft, R. L. (2008). The leadership experience, 4. Baskı, Mason: Thomson/ Learning Inc.

Davis, K., (1988). Işletmede insan davranışı, 5.Baskıdan Çeviri, Çev. Kemal Tosun, Tomris Somay, Fulya Aykar, Can Baysal, Ömer Sadullah ve Semra Yalçın, 3.Baskı, İstanbul: Yön Ajans.

Dedeoğlu, B. B., Aydın, Ş., \& Boğan, E. (2018). The role of the employees in the innovation of the hotel enterprises. Anais Brasileiros de Estudos Turísticos-

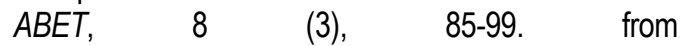
http://periodicos.ufff.br/index.php/abet/index

Demirel, Y. (2009). Örgütsel bağllık ve üretkenlik karşıtı davranışlar arasındaki ilişkiye kavramsal yaklaşım, İstanbul Ticaret Üniversitesi Sosyal Bilimler Dergisi, 8 (15), 115-132. from https://ticaret.edu.tr/uploads/kutuphane/dergi/s15/115132.pdf

Detert, J. R., Trevino, L. K., Burris, E. R. \& Andiappan, M. (2007). Managerial modes of influence and counterproductivity in organizations: A longitudinal business-unit-level investigation, Journal of Applied $\begin{array}{llll}\text { Psychology, } & 92 & \text { (4), } & \text { 993-1005. }\end{array}$ https://doi.org/10.1037/0021-9010.92.4.993

Dirican, A.H. (2013). Duygusal zekanın örgütsel vatandaşlık davranışı ve üretkenlik karşıtı davranışlar üzerine etkisi, Gebze Yüksek Teknoloji Enstitüsü Sosyal Bilimler Enstitüsü, Yüksek Lisans Tezi, Gebze.

Erdem, B. (2004). Otel işletmelerinde insan kaynakları planlamasının yeri ve önemi. Balıkesir Üniversitesi 
Sosyal Bilimler Enstitüsü Dergisi, 7 (11), 35-55. from http://sbe.balikesir.edu.tr/dergi/edergi/c7s11/makale/c $7 \mathrm{~s} 11 \mathrm{~m} 4 . \mathrm{pdf}$

Fox, S., \& Spector, P. E. (1999). A model of work frustrationaggression. Journal of Organizational Behavior, 20 (6), 915-931. from https://www.jstor.org/stable/3100373

Hollinger, R. C., \& Clark, J. P. (1983). Deterrence in the workplace: perceived certainty, perceived severity, and employee theft, Social forces, 398-418. https://doi.org/10.1093/sf/62.2.398

Kanten, P. \& Ülker, F. (2014). Yönetim tarzının üretkenlik karşııı iş davranışlarına etkisinde işe yabancılaşmanın araclık rolü, Muğla Sıtkı Koçman Üniversitesi Sosyal Bilimler Enstitüsü Dergisi, (32), 16-40. from http://www.sobbiad.mu.edu.tr/index.php/asd/article/vie w/467/457

Kessler, S. R., Bruursema, K., Rodopman, B. \& Spector, P. E. (2013). Leadership, interpersonal conflict, and counterproductive work behavior: An examination of the stressor-strain process, Negotiation and Conflict Management Research, 6 (3), 180-190. https://doi.org/10.1111/ncmr.12009

Kılıç, S. (2013). Algılanan örgütsel etik iklim ile üretkenlik karşıtı iş davranışları arasındaki iliş̧kiler. Yayımlanmamış Doktora Tezi, Niğde Üniversitesi Sosyal Bilimler Enstitüsü.

Le Roy, J., Bastounis, M. \& Minibas-Poussard, J. (2012). Interactional justice and counterproductive work behaviors: the mediating role of negative emotions, Social Behavior and Personality, 40 (8), 1341-1356. https://doi.org/10.2224/sbp.2012.40.8.1341

Liu Y, Lam, R. \& Loi R (2012). Ethical leadership and workplace deviance: The role of moral disengagement. In Advances In Global Leadership (p. 37-56), Emerald Group Publishing Limited, ISSN: 15351203/doi:10.1108/S1535-1203(2012)0000007006

Mann, S.L., Budworth, M. \& Ismaila, A.S. (2012). Ratings of counterproductive performance: the effect of source and rater behavior. International Journal of Productivity and Performance Management, 61 (2), 142-156. https://doi.org/10.1108/17410401211194653

Martinko, Mark J., Michael J. Gundlach \& Scott C. Douglas (2002). Toward an integrative theory of counterproductive workplace behavior: a causal reasoning perspective, International Journal of Selection \& Assessment, 10 (1/2), 36-50. https://doi.org/10.1111/1468-2389.00192

May, D. R., Hodges, T. D., Chan, A. Y. L \& Avolio, B. J. (2003). Developing the moral component of authentic leadership, Organizational Dynamics, 32, 247- 260. http://dx.doi.org/10.1016/S0090-2616(03)00032-9

Moretti, Donald M. (1986). The prediction of employee counterproductivity through attitude assessment, Journal of Business and Psychology, 1 (2), 134-147. http://dx.doi.org/10.1007/BF01018809

O'boyle, E. H., Forsyth, D. R. \& O'boyle, A. S. (2011). Bad apples or bad barrels: An examination of group-and organizational level effects in the study of counterproductive work behavior, Group \& Organization Management, 36 (1), 39-69. https://doi.org/10.1177/1059601110390998.
Pimentel, T. D., \& De Paula, S. C. (2019). Knowledge Production Systems in Tourism in Higher Education Institutions: Proposing A Performance Assessment Protocol Based on A Brazilian Experience. Journal of Multidisciplinary Academic Tourism, 4(1), 15-35.

Pimentel, T. D., Carvalho, F. C. C. D., \& Pimentel, M. P. C. (2019). The Institutionalization Process of the Formal Structures of Tourism Research (FSTR) in Brazil. Revista Brasileira de Pesquisa em Turismo, 13(3), 16-35.

Resick CJ, Hargis MB, Shao P \& Dust SB (2013). Ethical leadership, moral equity judgments, and discretionary workplace behavior. Human Relations, 66 (7): 951972. https://doi.org/10.1177/0018726713481633

Sabuncuoğlu, Zeyyat (2011). İşletme etiği, 1. Baskı, İstanbul: Beta Basım Yayım.

Sackett, P. R. (2002). The structure of counterproductive work behaviors: Dimensionality and relationships with facets of job performance, International Journal of Selection And Assessment, 10 (1-2), 5-11. https://doi.org/10.1111/1468-2389.00189

Scherer, R. Wiebe, F..A., Luther, D.C. \& Adams,J.S. (1988). Dimensionality of coping: Factorstability using the ways of coping questionnaire, Psychological Report, 62 , 763-770. https://doi.org/10.2466/pr0.1988.62.3.763

Sezgül, İ. (2010). Liderlik ve etik: geleneksel, modem ve postmodern liderlik tanımları bağlamında bir değerlendirme. Toplum Bilimleri Dergisi, 4 (7), 239-251.

Spector, P. E. \& Fox, S. (2002). An emotion-centered model of voluntary work behavior: Some parallels between counterproductive work behavior (CWB) and organizational citizenship behavior, Human Resources Management Review, 12, 269-292. http://dx.doi.org/10.1016/S1053-4822(02)00049-9

Spector, P.E., Fox, S., Penney, L.M., Bruursema, K., Goh, A. \& Kessler S. (2006). The dimensionality of counterproductivity: are all counterproductive behaviors created equal?, Journal of Vocational Behavior, $\quad 68 \quad(3), \quad 446-460$. https://doi.org/10.1016/j.jvb.2005.10.005

Şimşek, M. Şerif, Akgemci, T.\& Çelik, A. (2011). Davranış bilimlerine giriş ve örgütlerde davranış, 7. Baskı, Ankara: Gezi Kitabevi.

Taşlıyan, M., Hırlak B., Çiftçi G., ve Fidan E., (2016). Etik liderliğin örgütsel güven ve işe adanmışlık üzerine etkisi. 1.Uluslararası Sosyal Bilimler Kongresi Bildiriler Kitabı, 2541-2562. from https://www.researchgate.net/publication/318679804_ Etik_Liderligin_Orgutsel_Guven_ve_Ise_Adanmislik_ Uzerine_Etkisi

Tekeli, M., \& Buyruk, L. (2018). Konaklama işletmelerinde örgütsel adaletin işe yabancılaşma üzerine etkisi: Nevşehir'de bir araştırma. Journal of Multidisciplinary Academic Tourism, 3(2), 33-44. https://doi.org/10.31822/jomat.457364

Tuna, A. Akbaş ve Yasin Boylu (2016). Alglanan örgütsel destek ve işe ilişkin duyuşsal iyi oluş halinin üretkenlik karşıtı iş davranışları üzerine etkileri: hizmet sektöründe bir araştırma, Journal of Business 
Research

Turk,

https://doi.org/10.20491/isarder.2016.230

504-521.

Tuna, Muharrem, Hüdaverdi Bircan \& Murat Yeşiltaş (2012). Etik liderlik ölçeği'nin geçerlilik ve güvenilirlik çalışması: Antalya örneği, Atatürk Üniversitesi İktisadi ve Idari Bilimler Dergisi, 26 (2), 143-155. from https://dergipark.org.tr/atauniiibd/issue/2705/35705

Uche, N. \& Timinepere, C.O. (2012). Management styles and organizational effectiveness: an appraisal of private enterprises in eastern Nigeria. American International Journal of Contemporary Research, 2 (9), 198- 204. from

http://gssrr.org/index.php?journal=JournalOfBasicAnd Applied\&page $=$ article\&op $=$ view\&path $\% 5 B \% 5 D=8969$

Yaman, Adem (2010). İç denetçinin yeni rolü; Etik Liderlik,
Kamu lç Denetçileri Derneği Denetişim Dergisi, 9-16. from

https://www.researchgate.net/publication/323906512 IC_DENETCININ_YENI_ROLU_ETIK_LIDERLIK

Yen, C. \& Teng, H (2012). The effect of centralization on organizational citizenship behavior and deviant workplace behavior in the hospitality industry, Tourism Management, https://doi.org/10.1016/j.tourman.2012.10.003

Yeşiltaş, M., Çeken, H., \& Sormaz, Ü. (2012). Etik liderlik ve örgütsel adaletin örgütsel sapma davranışları üzerindeki etkisi. Muğla Üniversitesi Sosyal Bilimler

Enstitüsü Dergisi, 28, 18-39. $\quad$ From http://iibfdergi.nigde.edu.tr/article/view/5000066675

\section{APPENDIX}

Table 1: Demographic Data.

\begin{tabular}{|l|l|l|l|l|l|}
\hline Gender & Frequency & Percentage & Education & Frequency & Percentage \\
\hline Female & 69 & 27,4 & Primary School & 14 & 5,6 \\
\hline Male & 183 & 72,6 & Hihg School & 74 & 29,4 \\
\hline Total & 252 & 100 & Associate degrees & 85 & 33,7 \\
\hline Age & Frequency & Percentage & Graduated & 74 & 29,4 \\
\hline 24 age and belove & 100 & 39,7 & Undergraduated & 5 & 2 \\
\hline 25-34 ages & 109 & 43,3 & Toplam & 252 & 100 \\
\hline $35-44$ ages & 36 & 14,3 & Department & Frequency & Percentage \\
\hline 45 ages and above & 7 & 2,8 & Food\&Berage & 92 & 36,5 \\
\hline Total & 252 & 100 & Front Office & 53 & 21 \\
\hline Working Times & Frequency & Percentage & House Keeping & 73 & 29 \\
\hline 6 Month and below & 70 & 27,8 & Accounting & 17 & 6,7 \\
\hline $7-12$ months & 75 & 29,8 & Others & 17 & 6,7 \\
\hline 13-18 months & 41 & 16,3 & Total & 252 & 100 \\
\hline 19-24 months & 26 & 10,3 & Job Position & Frequency & Percentage \\
\hline 25 months and above & 40 & 15,9 & Lower Level & 181 & 71,8 \\
\hline Total & 252 & 100 & Mid Levels & 64 & 25,4 \\
\hline & & & Upper Level & 7 & 2,8 \\
\hline
\end{tabular}

Source: proper elaboration.

Table 2: Descriptive Factor Analyses for Ethical Leadership Behavior and Counterproductive Work Behaviors.

\begin{tabular}{|c|c|c|c|}
\hline Expressions for Ethical Leadership Behavior & 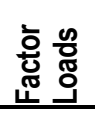 & 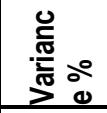 & ن \\
\hline \multicolumn{2}{|l|}{ Ethical Leadership Behavior } & \multirow{10}{*}{66,3} & \multirow{10}{*}{0,943} \\
\hline Managers try to make a fair and honest decision. & 0,842 & & \\
\hline Managers listen to the thoughts of employees. & 0,835 & & \\
\hline Managers share business ethics and ethical values with employees. & 0,834 & & \\
\hline Managers behave ethically to become an example to employees. & 0,823 & & \\
\hline Managers enforce disciplinary rules about unethical behavior. & 0,815 & & \\
\hline Managers want to protect their employees' interests in the best possible way. & 0,811 & & \\
\hline Managers behave ethically in their own personal lives. & 0,81 & & \\
\hline $\begin{array}{l}\text { Managers define success not only by results but also by the followed paths in which they } \\
\text { do it. }\end{array}$ & 0,801 & & \\
\hline Managers are trusted people. & 0,792 & & \\
\hline Managers get ideas from their employees about what should be the right thing to do. & 0,778 & & \\
\hline
\end{tabular}

Source: proper elaboration. 
Table 2: Continuing...

\begin{tabular}{|c|c|c|c|}
\hline Expressions on Counterproductive Work Behaviors & 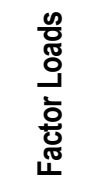 & 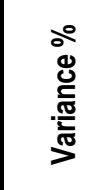 & $\frac{\frac{n}{5}}{\frac{N}{\widetilde{N}}}$ \\
\hline \multicolumn{2}{|l|}{ Abuse } & \multirow{19}{*}{30,03} & \multirow{19}{*}{0,968} \\
\hline I mocked someone's private life. & 0,795 & & \\
\hline I said demoralizing things to someone's face. & 0,784 & & \\
\hline I mocked someone or insulted him & 0,784 & & \\
\hline I made rude hand-arm gestures to someone & 0,782 & & \\
\hline I made a rude joke to embarrass someone. & 0,779 & & \\
\hline I did something to make someone look bad in front of everyone & 0,773 & & \\
\hline I deliberately ignored someone. & 0,772 & & \\
\hline I intimidated someone verbally. & 0,767 & & \\
\hline I threatened someone to commit physical violence. & 0,767 & & \\
\hline I behaved rudely to a citizen & 0,758 & & \\
\hline I discredit the work performance of an employee & 0,757 & & \\
\hline I used vulgar words to someone & 0,75 & & \\
\hline I hit/bullied somebody. & 0,748 & & \\
\hline I went through someone's personal belongings without permission & 0,743 & & \\
\hline I argued/brawled with somebody & 0,719 & & \\
\hline I made a bad rumor about someone or spread a bad rumor I heard & 0,71 & & \\
\hline I told the people around me how bad the hotel I work at is. & 0,702 & & \\
\hline I hold responsible someone for a mistake a did. & 0,694 & & \\
\hline \multicolumn{2}{|l|}{ Withdrawal } & \multirow{9}{*}{15,13} & \multirow{9}{*}{0,943} \\
\hline I left my shift early without permission & 0,815 & & \\
\hline I didn't go to work that day claiming to be being sick, even though I had no health problems. & 0,803 & & \\
\hline $\begin{array}{l}\text { I went to a medical facility to get away from work, and I showed myself on sick leave for } \\
\text { the day. }\end{array}$ & 0,801 & & \\
\hline $\begin{array}{l}\text { I have exceeded the predefined lunch and rest periods by the workplace without } \\
\text { permission. }\end{array}$ & 0,797 & & \\
\hline $\begin{array}{l}\text { I went to a health care facility to get a medical report so I wouldn't go to work for a few } \\
\text { days. }\end{array}$ & 0,781 & & \\
\hline $\begin{array}{l}\text { I left work without obtaining an hour's leave to take care of my private business during the } \\
\text { day. }\end{array}$ & 0,751 & & \\
\hline I came late to my shift without permission & 0,744 & & \\
\hline $\begin{array}{l}\text { I took a break from my job to go to the bathroom, to smoke etc., and I deliberately extended } \\
\text { it. }\end{array}$ & 0,605 & & \\
\hline \multicolumn{2}{|l|}{ Theft } & \multirow{6}{*}{10} & \multirow{6}{*}{0,893} \\
\hline I pretended to have worked more than my regular shift, and got paid extra. & 0,846 & & \\
\hline I took/used the money of the institution without permission. & 0,841 & & \\
\hline I took some of the hotel's equipment to my house without permission. & 0,826 & & \\
\hline I took something from one of the employees at the hotel without permission. & 0,782 & & \\
\hline I took something from the hotel without permission. & 0,674 & & \\
\hline \multicolumn{2}{|l|}{ Sabotage } & & \\
\hline I deliberately damaged a vehicle or equipment of the institution. & 0,73 & \multirow{5}{*}{8,18} & \multirow{5}{*}{0,815} \\
\hline I deliberately wasted our institution's tools and equipment. & 0,712 & & \\
\hline I deliberately left my office/workplace scattered. & 0,704 & & \\
\hline I deliberately left my office/workplace scattered. & 0,635 & & \\
\hline I deliberately damaged a vehicle or equipment of the hotel. & 0,599 & & \\
\hline \multicolumn{2}{|l|}{ Deviation from Production/Service } & \multirow{4}{*}{6} & \multirow{4}{*}{0,909} \\
\hline I refused a job I could do under normal circumstances, saying I couldn't handle it. & 0,786 & & \\
\hline I refused a job I could do under normal circumstances saying that I had medical problems. & 0,752 & & \\
\hline When there was an urgent work that needs to be done, I worked slowly on purpose. & 0,656 & & \\
\hline \multicolumn{2}{|c|}{$\begin{array}{l}\text { Reliability Analysis: 0,937 Total Variance: } 69,345 \text { Deductive Method: Principal Component Analysis } \\
\text { Kaiser Normalization with Varimax, Iteration No: } 6 \\
\text { KMO Compliance Criteria: } 0,935 \text { Barlett Globality Test x2: } 9080,502 \quad \text { p: } 0,000\end{array}$} & \multicolumn{2}{|c|}{ Spinning Method } \\
\hline
\end{tabular}

Source: proper elaboration. 
Table 5: Regression Analysis.

\begin{tabular}{|l|l|l|l|l|l|l|l|}
\hline $\begin{array}{l}\text { Name of } \\
\text { Model }\end{array}$ & Independent Variable & Dependent Variable & Beta & $\mathbf{t}$ & $\mathbf{P}$ & $\mathbf{R}^{\mathbf{2}}$ & $\mathbf{F}$ \\
\hline 1. Model & Ethical Leadership & Counterproductive Work Behaviors & $-0,398$ & $-6,856$ & 0 & 0,158 & 47,01 \\
\hline 2. Model & Ethical Leadership & Abuse & $-0,42$ & $-7,308$ & 0 & 0,176 & 53,41 \\
\hline 3. Model & Ethical Leadership & Withdrawal & $-0,252$ & $-4,125$ & 0 & 0,064 & 17,05 \\
\hline 4. Model & Ethical Leadership & Theft & $-0,17$ & $-2,728$ & 0,007 & 0,029 & 7,441 \\
\hline 5. Model & Ethical Leadership & Sabotage & $-0,185$ & $-2,983$ & 0,003 & 0,034 & 8,899 \\
\hline 6. Model & Ethical Leadership & Production/Service Deviation & $-0,402$ & $-6,937$ & 0 & 0,161 & 48,12 \\
\hline
\end{tabular}

Source: proper elaboration.

Recebido/ Received: May 12, 2019; Aceito/Accepted: November 26, 2019; Publicado/Published online: December 5, 2019. Artigo original / Original paper. Seção revisada por pares / Double blind review section. 